\title{
SUBMICROSCOPIC STRUCTURE OF SYNOVIAL MEMBRANE IN THE ADULT PIG
}

\author{
D. HORKÝ \\ Department of Anatomy, Histology and Embryology \\ University of Veterinary Science, 61242 Brno \\ Received September 15, 1989
}

\begin{abstract}
Horký, D.: Submicroscopic Structure of Synovial Membrane in the Adult Pig. Acta vet. Brno 60, 1991: 3-13.

The synovial membrane of adult pigs was investigated. Samples were obtained from hip joints of pigs of both sexes at 15 to 24 months after birth. The tissues were processed in the routine manner to be examined by light and transmission electron microscopy.

The synovial membrane in adult pigs involved two types of synovialocytes, $A$ and $B$, which were arranged on its surface in 2 to 3 layers. Type A cells near the surface presented as single cells while B cells formed small clusters. These contained, apart from typical fully differentiated cell types, also transient $\mathbf{A}-\mathbf{B}$ types which had all characteristics of $A$ cells together with bodies corresponding in size and appearance to secretory granules of B cells. The cytoplasm of both A and B cells showed the presence of intracytoplasmic filaments. Type A cells had the basal membrane while in type B cells this was absent.

Near the membrane surface the fibrillar component of synovial matrix consisted of collagen fibrils which, in areas penetrated with synovialocyte projections, were unmasked and protruded into the articular cavity. In surface layers, aperiodic filaments were prevailing while towards deeper layers increasing numbers of typical collagen fibrils running in various directions were observed. Aperiodic collagen fibrils penetrating through the B-cell membrane were seen repeatedly. When approaching the cell membrane they attained a periodic appearance.
\end{abstract}

\section{Synovial membrane, $A, B, A-B$ synovialocytes, matrix synovialis}

The synovial membrane plays a major role in both physiology and pathology of the joint. This has been a reason for thorough studies of its building units, i.e. cells and intercellular matter. Even though these building elements have been investigated for nearly 250 years (Hunter 1743 - see Ghadially 1983), the information is still incomplete. At first attention was given to the synovial membrane of adults in experiments with mammalian animal species and later in man. Many authors have studied and described the microscopic structure of synovial membrane under physiologic, experimental and pathologic conditions (for review see Horký 1981; Ghadially 1982). The present trend, which is to gain a deeper insight into its structure and particularly into the development of its functions in relation to advancing differentiation, makes the use of young unmature animals including embryos (for review see Horký 1984, 1989ab).

The submicroscopic structure, histochemical and cytochemical properties, and immunohistochemical characteristics have been reported under physiologic and pathologic conditions in different mammalian and avian species (Langer and Huth 1960; Barland et al. 1962; Cutlip and Cheville 1973; Horký et al. 1975; Fell et al. 1976; Linek and Porte 1978; Horký 1981, 1984, 1989ab; Ghadially 1982; Okada et al. 1981; T offt and Effendy 1985; Karatzias et al. 1986; Gaines et al. 1987; Itokazu et al. 1988; Lukoschek et al. 1988) and others. These observations revealed the presence of two types of synovial cells in the synovial membrane of all the species so far studied. These are: i) A or $M$ (macrophage-like) cells reminiscent of histiocytes by their structure, showing phagocytic properties (Ball et al. 1964; Fell et al. 1976; Horký et al. 1974; Mapp ad Revell 1988); ii) B or F (fibroblast-like) cells or S (secretory) cells which, in 
most mammals, are characterized by a well-developed granular endoplasmic reticulum, a large Golgi complex and the presence of secretory granules. These cells have been reported by Barland et al. (1962), Johanson and Rejnö (1976), Okada et al. (1981), Horký (1984, 1989ab), Graabaek (1984) and others in the whole range of mammalian species.

The synovial membrane in pigs has so far received little attention. The first more detailed data were published by Roberts et al. (1969) who studied the structure of synovial membrane in femoropatellar and tibiotarsal joints in pigs at 1 day and at 2 months after birth. Further results were reported by Fell et al. (1976) who made investigations of synovialocyte structure in metacarphophalangeal joints of pigs at 18 weeks of age and of cell behaviour in synovialocyte cultures grown in vitro for 6 days. Horký has reported $(1989 \mathrm{ab})$ the submicroscopic structure of synovial membrane of the hip joint in the prenatal and early postnatal periods and has also been concerned with the arrangement of intercellular matter of synovial membrane. These studies have been completed by the results presented in this paper which deals with the submicroscopic structure of synovial membrane in adult pigs.

\section{Materials and Methods}

Samples of porcine synovial membrane were obtained from 5 pigs of both sexes at 15 to 24 months after birth. The tissue was collected in all instances from the hip articular capsule and processed for examination by light and electron microscopy. The samples of synovial membrane including part of subsynovial tissue were carefully dissected into strips ( 1 by 1 by $2-3 \mathrm{~mm}$ ) in a drop of fixation liquid. Immediately, the strips were fixed in glutaraldehyde $(300 \mathrm{mmol} / 1)$ in $0.1 \mathrm{M}$ phosphate buffer ( $\mathrm{pH} \mathrm{7.4)}$ for 60 then $180 \mathrm{~min}$. and rinsed in three fresh baths of $0.1 \mathrm{M}$ phosphate buffer (pH 7.4). Fixation was carried out in $40 \mathrm{mmol} / 1 \mathrm{OsO}_{4}$ in phosphate buffer $(\mathrm{pH} 7.4)$ for 15 and $45 \mathrm{~min}$. The specimens were dehydrated in two baths with anhydrous acetone for $30 \mathrm{~min}$. each. Immersion was performed in the standard way and the tissues were embedded in Durcupan ACM. Polymerization took place in an oven at $60^{\circ} \mathrm{C}$ for 3 days. Ultrathin sections were cut with an Ultracut Reichert ultramicrotome, stained with lead citrate according to Reynolds or with $1 \%$ uranyl acetate followed by lead citrate. The sections were examined and photographed with a Tesla BS 500 microscope. Semithin sections for light microscopic observations were made from the same Durcupan embedded blocks and stained with $1 \%$ methylene blue and Azure II.

Fig. 1 to 8 are placed on Plates $I$ to VI at the and of this volume.

\section{Results}

\section{Submicroscopic structure of synovial membrane cells}

The synovial membrane of adult pigs was covered with three or, in some regions four layers of cells. Synovialocytes were embedded in the matrix synovialis which made up a thick layer above them towards the articular cavity (Fig. 1). In the opposite direction they continued into the subsynovial tissue without forming any sharp boundary. Type A and type B cells were unevenly distributed in the respective layers of the synovial membrane.

\section{Ultrastructure of type A cells}

A cells in the porcine synovial membrane were less numerous than B cells. They were seen near the membrane surface as single cells (Figs 1,2,3) or in aggregates of 2 to 3 cells among type B cells. Apart from typical A cells, transient $A-B$ form were also found.

\section{Nucleus}

It was usually oval in shape (Fig. 2) and about 8 by $3-4 \mu \mathrm{m}$ in size. The nuclear envelope of the usual arrangement sent wide shallow invaginations against the karyoplasm (Fig. 2). The perinuclear shape was mostly narrow, but in some areas was dilated up to $0.1-0.2 \mu \mathrm{m}$ (Fig. 2). The zonula nucleum limitans was seen as a continuous line (maximum $0.1 \mu \mathrm{m}$ ) along the inner membrane of 
the nuclear envelope (Fig. 2). Chromatin was arranged into a continuous layer at the nuclear periphery or was found as small karyosomes on sections through the nucleus. The continuous layer was closely attached to the zonula nucleum limitans and on few occasions was interrupted with nuclear pores (Fig. 2).

$\mathrm{Nucleoli}$ were rare and, when seen, of reticular types.

\section{Cytoplasm}

The granular endoplasmic reticulum was observed in the cytoplasm of A cells as few short and flattened cisternae (Fig. 1,2) with scarce ribosomes.

The agranular endoplasmic reticulum, most pronounced in A cells near the membrane surface, formed large vacuoles and small vesicles (Plate I.), Fig. 1). The big vacuoles usually contained material of varying appearance and density. It is possible that some of the vacuoles were secondary lysosomes. The small vesicles were either coated-vesicles or more often vesicles of uniform appearance likely to have pinocytotic function. Identical structures could also be seen on sections through cytoplasmic projections of A cells (Fig. 1). Some of the $0.3-0.4 \mu \mathrm{m}$ vesicles Plate II.,(Fig. 2) were filled with finely granulated, medium electron-dense material. These vesicles were regarded as transport vacuoles.

The Golgi complex was not well developed in the cytoplasm of A cells. It included occasional smooth vacuoles and the transport vacuoles mentioned above.

Mitochondria had the usual structure and were few in number. Some had an elongated shape and attained a length of $2-3 \mu \mathrm{m}$. Apart from them, some forms with markedly dense matrix were also seen (Fig. 1). Mitochondria with transparent matrix (Fig. 2) were observed mostly in cells' cytoplasmic projections.

Ribosomes were numerous and, apart from the few ribosomes attached to the outer membrane of the nuclear envelope and to cisternae of the granular endoplasmic reticulum, they were diffusely distributed in the cytoplasm. This gave the cytoplasm a dark appearance.

No centrioles were found in A cells of the synovial membrane of adult pigs. Because synovialocytes were not in close contact with each other, the intercellular supporting structures such as zonula occludens, zonula adherens and desmosomes could not be seen either.

Cell membrane. Cross sections showed the C-cell cytoplasm sending many projections, several $\mu \mathrm{m}$ long and considerably thick, into the surrounding matrix synovialis (Fig. 2). The projections contained cytoplasm with all the cell organelles and a markedly high number of pinocytotic vesicles (Fig. 1).

Neither lipid droplets not glycogen were observed in the tissues under study.

Intracytoplasmic filaments occurred only occasionaly as thin bands of fibres, $5 \mu \mathrm{m}$ thick, scattered in the cytoplasm. These were vimentine filaments belonging to the cytoskeleton structures. Type A cells were found to be separated from the surrounding matrix with a distinct, though partly incomplete, basement membrane (Fig. 1, 2).

\section{Ultrastructure of transient type cells}

Apart from typical type A and type B cells, the synovial membrane also included transient type cells (A-B cells) which combined submicroscopic characteristics of both types. They were seen occasionally within groups of 2 to 3 type A cells present in the vicinity of B cells. 


\section{Nucleus}

It was pear-shaped and had similar dimensions as A-cell nuclei. The nuclear envelope had the usual arrangement with the exception of the perinuclear space which was distended along the whole nuclear periphery (Plate III., Fig. 3). The inner nuclear membrane was lined with zonula nucleum limitans corresponding in appearance and thickness to that of A-cell nuclei. Chromatin was aggregated into large karyosomes situated near the nuclear envelope. The rest of the nucleus was transparent containing a low number of small chromatin clusters. Occasional perichromatin granules were present (Fig. 3). The size of a compact type nucleolus was $2.5-3 \mu \mathrm{m}$. (Fig. 3).

\section{Cytoplasm}

The granular endoplasmic reticulum consisted of short flattened cisternae and broadly dilated sacks with amorphous or filamentous medium electron-dense material.

The agranular endoplasmic reticulum was arranged in a way typical of A cells. Near the surface there were numerous large vacuoles $(1-1.5 \mu \mathrm{m})$ with an electron-transparent appearance. In addition, there were unevenly distributed small smooth vesicles filled with finely granulated or filamentous material and large numbers of small smooth vesicles of agranular endoplasmic reticulum.

The Golgi complex was well formed. It involved several fields and its structures were usually dilated (Fig. 3). Its cisternae sequestered small Golgi vesicles with dark, either granulated or homogeneous content. Most of these remained in the vicinity of the complex but some could be seen scattered in the cytoplasm or cytoplasmic projections. They were similar in appearance to secretory granules of B cells (see below) or to transport vacuoles of A cells.

Mitochondria had the usual appearance and arrangement. No dark or very light mitochondria with damaged cristae or clear matrix were observed.

Ribosomes did not differ from those of B cells in either amount or arrangement.

Lysosomes were a regular finding in the cytoplasm of transient type cells. They were present in the cytoplasm near the nucleus or in cytoplasmic projections (Fig. 3).

Similarly to A cells, no centrioles were found in the transient type cells.

Cell membrane. The cytoplasm of transient type cells produced a few short cytoplasmic projections (Fig. 3). These contained cytoplasm of the same composition as was that found close to the nucleus. The cell membrane produced a lower number of pinocytotic vesicles than that in A cells and the basement membrane was not formed.

Intracytoplasmic filaments showed no difference in either appearance or arrangement as compared with those in synovialocytes of type A cells.

\section{Ultrastructure of type $B$ cells}

When compared to type A cells, B cells were found to be the prevailing cell population of the synovial membrane. They were observed in the deeper parts of the membrane in the form of groups or small clusters embedded in the synovial matrix. In contrast to A cells, they took the shape of an irregular polyhedron, an irregular oval or an elongated cylinder (Plate IV., Fig. 4). 


\section{Nucleus}

It was irregular in shape. Its size was about 7.5 by $3.5-4 \mu \mathrm{m}$. The nuclear envelope arranged in the usual manner formed deep invaginations against the karyoplasm (Fig. 4) thus giving the nucleus a lobular appearance. The zonula nucleum limitans had the same width as in A cells. Chromatin was concentrated into a narrow layer along the nuclear periphery, leaving the remaining nucleus to appear very light except for several where perichromatin bodies were surrounded with chromatin. The accumulation of chromatin, presenting as so-called perinucleolar chromatin, could be seen near the nucleolus. Nuclear pores were more numerous than in the other cell types.

Cross sections through the nucleus regularly revealed nucleoli, $1-1.8 \mu \mathrm{m}$ in size (Fig. 4) which always included nucleolonema. On rare occassions segregation of the pars granulosa or the pars fibrosa was seen.

\section{Cytoplasm}

B cells had cytoplasm with a markedly large granular endoplasmic reticulum (Figs. 4, 5, 6). This consisted of many narrow cisternae varying in length, filled with medium-osmiophilic, finely granulated or filamentous substance (Plate V., Fig. 5, 6). Even though the endoplasmic reticulum was very rich in cisternae, no close relation to any of the other organelles was revealed. In some type B cells the cytoplasm near the nucleus had a region where membrane structures were arranged in parallel layers. These were reminiscent of anular membranes (membranae annulatae) (Plate VI., Fig. 7).

The agranular endoplasmic reticulum presented as occasional smooth vesicles, $0.2-0.3 \mu \mathrm{m}$, both in the cytoplasm and near the cell membrane. The vesicles were electron-transparent.

The Golgi complex was well developed. It spread over several fields (Figs $4,5,6,7,8)$ taking up a large part of the cytoplasm. The structure was typical. The dilated cisternae sequestered small and large Golgi vacuoles which passed to the surrounding cytoplasm as secretory granules, lysosomes or transport vacuoles (Figs 4, 5, 6, 7, 8).

Mitochondria had the usual structure. The most frequently occurring mitochondria were $1-1.5 \mu \mathrm{m}$ long with markedly dark matrix (Figs 4,5 ). Their number was much higher than in A cells.

Lysosomes were hardly discernible in the electron micrographs. Since no histological proof was produced, it was not possible to distinguish them from secretory or transport granules.

Secretory granules were conspicuous structures of the B-cell cytoplasm. They occurred in large numbers and attained a size of $0.5-0.8 \mu \mathrm{m}$. They were bounded with a smooth membrane and contained granular or homogenous material of varying density (Figs 4, 5, 7, 8). Some of them had lighter peripheries and darker centres (Plate VI., Fig. 8), which made them reminiscent of heterogenous prozymogen granules. Other granules (Fig. 7) were similar to coated vesicles.

Centrioles were frequently present in the B-cell cytoplasm (Figs 4, 5). They showed the usual arrangement and were seen in various parts of the cytoplasm.

Cell membrane. In type B cells the cytoplasm occasionally sent out short thin projections and thick projections. The thin ones were free from organelles or secretory granules, while the cytoplasm of the thick projections had the same 
content as that of the cell (Figs 7,8). The cell membrane segregated a lot of pinocytotic vesicles (Figs 4,7).

Intracytoplasmic filaments were a rare finding. In B cells the penetration of collagen fibrils through the cell membrane was frequently observed (Figs 5,6). As can be seen in Fig. 6, these fibrils arose from the content of transport vacuoles travelling towards the cell membrane. Tropocollagen was spilled onto the surface and the following polymerization produced collagen fibrils which showed the signs of periodicity (Figs 5,6).

\section{Synovial matrix}

This is generally characterized as an intercellular substance, originating from mesenchyme, which provides a specialized environment for synovialocytes. As with other mesenchymal tissues, it consists of the ground fibrillar substance and the ground amorphous substance.

In the synovial membrane of the adult pig, the ground fibrillar substance was made up of two types of fibrils. First, typical collagen fibrils, $60-100 \mathrm{~nm}$ thick and several $\mu \mathrm{m}$ long, which were branched and showed a periodicity of $64 \mathrm{~nm}$. Second, aperiodic fibrils about $50 \mathrm{~nm}$ in thickness and $0.1 \mu \mathrm{m}$ in length or, on rare occasions, longer. These two kinds of fibrils were observed in the cisternae of the granular endoplasmic reticulum of both types of synovialocytes. Similar findings have been made by Wassilev (1975), Ghadially (1983) and Horký $(1984,1989 \mathrm{ab})$ in the synovial membranes of various other mammalian species.

The ground amorphous substance was composed of the protein-hyaluronic acid complex and sulphonated mucopolysaccharides. The two components were visualized by electron microscopy as finely granulated, medium-osmiophilic matter present among collagen fibres. They both probably migrated into the synovial fluid, taking part in lubrication processes (Hills and Butler 1984).

In the adult pig, the synovial matrix varied in arrangement from place to place in relation to the distribution of synovialocytes. In areas where the cells were situated near the surface of the synovial membrane (Fig. 1) the surface consisted largely of parallel bundles of aperiodic filaments. These were embedded in a relatively small amount of ground amorphous substance which produced a layer at the boundary of the articular cavity. More fibrillar structures, i. e. irregularly running aperiodic filaments and collagen protofibrils, thin collagen fibrils showing periodicity, were seen in the amorphous substance at the side of synovialocytes or in deeper layers of the synovial membrane. Aperiodic filaments in close contact with the synovialocyte cell membranes were frequently observed (Figs $1,2,3)$.

In the regions where the cells occurred in deeper layers and the surface of the synovial membrane was formed mostly by their cytoplasmic projections, the surface showed a different arrangement. Numerous cytoplasmic projections were present in the ground amorphous substance while the fibrillar component was considerably reduced in amount (Fig. 2). Aperiodic filaments were present in low numbers and collagen fibrils near the surface were a rare finding. Some of the cytoplasmic projections were unmasked and got in direct contact with the articular cavity (Fig. 2). A large number of collagen fibrils could be found close to the cell membranes of synovialocytes facing the deeper layers of the synovial membrane (Figs 2,4 ). In the two regions of synovial membrane, collagen fibrils were observed behind the basement membrane. 


\section{Discussion}

The synovial membrane is a tissue originating from mesenchyme. It provides lining for the articular fissure. Its structure is generally that of connective tissues but the cells, which form a monolayer or a multilayer cover, differ from the other cells of connective tissue in morphology and function. The synovial membrane arises from the original skeletal blastema during development (Andersen 1964; St off and Effendy 1985). The cells covering the synovial membrane surface are regarded as modified mesothelial cells even though they do not produce a continuous layer and are not interconnected by intercellular bridges such as desmosomes or zonulae occludentes, etc. It has been known that synovial cells are segregated-from the surface and are replaced with cells proliferating from the subsynovial layer; this is particularly obvious during inflammatory diseases (Ghadially 1983). As shown by experiments using ${ }^{3} \mathrm{H}$-thymidine, the labelled cells appear in the normal synovial membrane only occasionally. Their numbers, however, increase following experimental inflammation or partial synovectomy, which was demonstrated by Schulitz (1974) in the synovial membrane of rabbits. A typical feature of this tissue is the absence of neural endings. Occasionally seen nerve fibres are autonomous fibres of vascular adventitia (Halata and Groth 1976; Knight and Lewick 1983).

The function of synovial membrane has been studied thoroughly. Evidence obtained up to the present suggests two principal roles:

(1) production of synovial fluid

(2) exchange and removal of synovial fluid and cell detritus related to the articular cavity.

The articular fluid is a specific plasma transudate enriched with substances excreted by type B synovialocytes; this was demonstrated by Swann in 1978 . and recently by other authors who studied relationships between the synovial fluid and the articular cartilage with respect to nutrition and, particularly, to the mechanics of articular movement (Sokol off 1980; Swann et al. 1981, 1984, 1985; Hills and Butler 1984; Sabiston and Adams 1989) or in association with the role of enzymes in degradation processes (Krane and Amento 1983; Markowitz 1983; Dingle 1984; Gangel 1984). The finding that hyaluronic acid (non-sulphonated glycosamine glycan) is transferred to the synovial fluid was made a long time ago (Lever and Ford 1958) and re-confirmed recently (Hilbert et al. 1984). All the components of synovial membrane, excluding digestive enzymes, are involved in the nourishment of the articular cartilage and in lubrication qualities of the synovial fluid. The other role of the synovial membrane, i. e. removal of cell detritus, has been reported by Ball et al. (1964) and similar data were presented by Horký et al. (1974) in hemarthrosis.

The synovial membrane surface has a villous character. In different areas. ist appearance varies in relation to the state of the membrane under either physiologic or pathologic conditions. This was studied by scanning electron microscopy by Kondoh (1973), Gaucher et al. (1976) Horký (1981) and Ghadially (1983).

Synovial cells are embedded in the matrix synovialis whose density ranges from low to medium values. The intercellular matter includes typical collage fibrils showing periodicity, aperiodic collagen fibrils and fine aperiodic filaments situated in the amorphous substance (Meachim and Stockwell 1979; Horký 
1981, 1984, 1989ab). Collagen fibrils of typical appearance are present in greater amounts in the deeper parts of the membrane, while near the surface the predominant fibrillar components are collagen fibrils without periodicity and periodic filaments. One of the explanations has suggested that collagen fibrils in deep layers are gradually disintegrated down to aperiodic filaments (Ghadially 1983) but from the data on functions of type A synovialocytes and from the morphological evidence on the ability of fibrills to pass through the cell membrane (Horký $1981,1984,1989 \mathrm{ab}$ ) it seems more probable that this process takes the other way round.

Although the microscopic and submicroscopic structures of the synovial membrane have been studied in a great range of mammalian species (Langer and Huht 1960; Barland et al. 1962; Cutlip and Cheville 1973; Fell et al. 1976; Linck and Porte 1978; Okada et al. 1981; Horký 1981, 1984), the information on the synovial membrane in the pig is scarce. The in vivo structure was described by Fell et al. (1976) who were also interested in the behaviour of synovialocytes in vitro. The ultrastructure of the porcine synovial membrane has only been studied during the prenatal and early postnatal periods (Horký $1989 \mathrm{ab})$. Thus the observations presented here can be compared with our previous results obtained in the pig or with those concerning the bovine synovial membrane.

A characteristic feature of the porcine synovial membrane under study was a mixed population of fully differentiated type A and type B cells and transient A-B cells. The distribution of the respective types was similar to that reported in the adults of other mammalian species excluding the rat (Wassilev 1975). To distinguish between them is not difficult and it is based on distinct appearances of the cytoplasm related to the presence of organelles and secretory granules. These bodies have been described in adult animals of several mammalian species (Ghadially and Roy 1969; Linck and Porte 1978; Graabaek 1984) and in the prenatal and early postnatal periods of different mammals including man (Horký 1981, 1984, 1989ab). They have been given various names and the opinions on their origin, composition and function are diverse. The results published by Linck and Porte (1978) and particularly Okada et al. (1981) and Graabaek $(1984,1985)$ demonstrated that in formation of secretory granules a major role is played by the granular endoplasmic reticulum and Golgi complex. Okada et al. (1981) and also Graabaek $(1984,1985)$ showed that, in contrast to A-cell lysosomes, the secretory granules of B cells do not contain acid phosphatase but have mucopolysaccharides and glycoproteins bound to a protein carrier, which could be proved by protein digestion.

Apart from the distinct types of synovialocytes, our observations included also cells where the presence of cellular organelles was indicative of A cells but which also contained secretory granules. These fi idings supported our earlier view (Horký et al. 1974, 1975, 1981, 1984, 1989ab) as well as the views of other authors (Fell et al. 1976; Linck and Porte 1978; Okada et al. 1981) that transformation of type A and B cells and vice versa is possible and depends on the species of the animal and its age and the physiologic state of the joint (Cutlip and Cheville 1973). In addition, Linck and Porte (1978) and Fell et al. (1976) ascertained that this reflects functional flexibility of the synovial membrane and not the loss of cell function.

In comparison with the porcine foetal synovial membrane, the synovialocytes under study regularly involve intracytoplasmic filaments (Lazarides 1980; 
Horký 1984, 1989ab). In adulthood, type A cells of synovial membrane form basement membranes which are absent in the A cells of the prenatal and perinatal periods and in B cells (Horký 1989ab). As seen previously in cattle in the prenatal and perinatal periods (Horký 1989) and in the same periods in the pig (Horký 1989ab), collagen fibrils were able to pass through the cell membranes of $B$ cells. Thus the designation of B cells as $S$ (secretory) cells, based on production of various substances, is fully justified.

\section{Submikroskopická struktura synoviální membrány prasete v dospělosti}

Byla sledována synoviální membrána dospělých prasat. Vzorky byly získány z kyčelních kloubů 5 jedinců obojího pohlaví stáří $15-24$ měsíců po narození. Materiál byl zpracován pro účely světelné a transmisní elektronové mikroskopie standardním způsobem.

Synoviální membrána dospělých prasat je tvořena A a B typy synovialocytů, které jsou na jejím povrchu uloženy ve $2-3$ vrstvách. Blíže povrchu se vyskytují $A$ buňky převážně jednotlivě, zatímco $B$ buňky vytvářejí malé shluky. $V$ nich se kromě typických již plně diferencovaných typů vyskytují přechodné tzv. A-B typy. Jedná se o buňky, mající všechny znaky A buněk, ale navíc obsahuji tělíska vzhledem i velikostí identická se sekrečními granuly B buněk. V cytoplasmě jak $A$, tak především $B$ buněk se vyskytují intracytoplasmatická filamenta. Buňky $\mathrm{A}$ jsou ohraničeny bazální membránou, zatímco u B buněk tato membrána chybí.

Vláknitá složka synoviální matrix je tvořena na povrchu jednotlivými kolagenními fibrilami, které $\mathrm{v}$ úsecích, kde $\mathrm{k}$ povrchu pronikají pouze výběžky synovialocytů, jsou demaskovány a prominuji do kloubni dutiny. $\mathrm{V}$ povrchových vrstvách převažuji aperiodická filamenta, směrem do hlubších vrstev přibývá typických kolagenních fibril, probíhajících různými směry. Zachytili jsme opakovaně průnik aperiodických kolagenních fibril buněčnou membránou $\mathrm{B}$ buněk. Tyto fibrily v blízkosti buněčné membrány získaly periodicitu.

\section{Субмикроскопическая структүра синовиальной мембраны взроспых свиней}

Проводили исследования синовиальной мембраны взрослых свиней. Образцы получили из тазобедренных суставов 5 особей обоих полов в возрасте 15-24 месяца после опороса. Материал обрабатывали с целью его использования в световой и трансмиссионной электронной микроскопии стандартным способом.

Синовиальная мембрана взрослых свиней состоит из синовиалоцитов типа А и В, расположенных на поверхности в 2-3 слоях. Ближе к поверхности встречаются клетки А преимүщественно в одиночку, между тем как клетки В образуют небольшие скопления. В них помимо характерных полностью уже дифференцированных типов встречаются переходные, так называемые А - В типы. Речь идет о клетках со всеми характерныме чертами клеток $A$, содержащих вдобавок тельца, по виду и размеру идентичные с секреторными гранулами клеток В. В цитоплазме А-клеток и, главным образом, В-клеток встречаются интрацитоплазматические филаментарные волокна. Клетки А ограниче- 
ны базальной мембраной, между тем как у клеток В данной мембранью нет.

Волокнистая составляющая синовиального слоя на поверхности состоит из отдельных коллагенных фибрилл, которые в местах проникновения к поверхности пишь выступов синовиалоцитов открыты и выходят в суставную полость. Преобладающими в поверхностных слоях являются апериодические филаментарные волокна, в глубоких слоях увеличивается число характерных коллагенных фибрилл, проходящих в разном направлении. Нами повторно было установлено проникновение апериодических коллагенных фибрилл клеточной мембраной клеток В. Данные фибриллы вблизи клеточной мембраны отличались периодичностью.

\section{References}

ANDERSEN, H.: Development morphology and histochemistry of the early synovial tissue in human foetuses. Acta Anat., 58, 1964: 90-115

BALL, J.-CHAPMAN, J. A.-MUIRDEN K. D.: The uptake of iron rabbit synovial tissue following intraarticular injection of iron dextran. A light and electron microscope study. J. Cell Biol., 22, 1964: 355-364

BARLAND, P.-NOVIKOFF, A. B. - HAMERMAN, D.: Electron microscopy of the human synovial membrane. J. Cell Biol., 14, 1962: 207-220

CUTLIP, R. C.-CHEVILLE, N. F.: Structure of synovial membrane of sheep. Am. J. vet. Res., 34, 1973: 45-50

DINGLE, J. T.: The effect of synovial catabolin on cartilage synthetic activity. Conn. Tissue Res., 12, 1984: 277-287

FELL, H. B.-GLAUERT, A. M.-BARRAT, M. E. J.-GREEN, R. E.: The pig synovium $I$. The intact synovium in vivo and in organ culture. J. Anat., 122, 1976: 663-680

GAINES, J. J. Jr. - TOM, G. D. - KHANKHANIAN, N.: An ultrastructural and light microscopic study of the synovium in ochronotic arthropathy. Human Path., 18, 1987: 1 160-1 164

GANGEL, H.: Synovial fluid. In Diseases of the Horse. Basel: O. Dietz, E. Wiesner, S. Karger AG 1984

GAUCHER, A.-FAURE, G.-NETTER, P.: Application of scanning electron microscopy in the evolution of iron content of human synovial membrane. Sem. Hop. Paris, 52, 1976: $1543-1544$

GHADIALLY, F. N.: Ultrastructural pathology of the cell and matrix. London: Butterworths. 1982

GHADIALLY, F. N.: Fine structure of synovial joints. London: Butterworths 1983

GHADIALLY, F. N.-ROY, S.: Ultrastructure of synovial joint in health and disease. London: Butterworths 1969

GRAABAEK, P. M.: Characteristics of the two types of synoviocytes in rat synovial membrane. An ultrastructural study. Lab. Invest., 50, 1984: 690-702

GRAABAEK, P. M.: Fine structure of the lysosomes in the two types of synovialocytes of normal rat synovial membrane. A cytochemical study. Cell Tissue Res., 239, 1985: 293-298

HALATA, Z. - GROTH, H. P.: Innervation of the synovial membrane of the cat's joint capsule. Cell Tissue Res., 169, 1976: 415-432

HILBERT, B. J.-ROWLEY, G.-ANTONAS, K. N.: Hyaluronic acid concentration in synovial fluid from normal and arthritic joints of horses. Anat. vet., J., 61, 1984: 22-24

HILLS, B. A.-BUTLER, B. D.: Surfactants indentified in synovial fluid and their ability toact as boundary lubricants. Ann. rheumat. Dis., 43, 1984: 641-648

HORKY, D.: Submicroscopic structure of the human joint cartilage and synovial membrane in ochronosis. Acta vet. Brno, 50, 1981: 131-156.

HORKY, D.: Ultrastructure of the bovine synovial membrane in ontogenesis. Acta vet. Brno, 53, 1984: $107-117$

HORKY, D.: Ultrastructure of pig synovial membrane of prenatal period. Acta vet. Brno, 59, $199013-21$

HORKY, D.: Ultrastructure of porcine synovial membrane of early postnatal period. Acta vet. Brno, 59, 1990b: 111-119

HORKY, D. - BOZDĚCH, Z. - HORN, V.: Ultrastructure of the synovial membrane and articular cartilage in haemonhilic in the transmission and scanning electron microscope. Folia morphol. (Prague), 22, 1974: 330-334 
HORKÝ, D. - BOZDĚCH, Z.-HORN, V.: Die Struktur der Synovialmembrane in Transmission - und Rasterelektronen nikroskop. Acta Fac. Med. Univ. Brun. 52, 1975: 241-249

HUNTER, W.: On the structure and diseases of acticulating cartilages. Phil. Trans. Roy. Soc., B42, 1743: 514-521

ITOKAZU M.-BIADLEY, J.-FRANCIS, M. J. O.-DUTHIE, R. B.: Localization of speciric carbohydrate conizurations in the hemophilic synovial membrane. Clin. orthop. relat. Res., 230, 1988: 284-288

JOHANJSON, H. E.-REJNÖ, S.: Light and electron microscopic investigation of equine synovial membrane. A comparison between healthy joints with intraarticular fractures and osteochondrosis dissecans. Acta vet. scand., 17, 1976: 153-168

KARA TZIAS, H.-MEERMANN, A. -STOBER, M.: Total protein concentration and protein fractions of synovia and blood serum in cattle with normal joint and in cattle with aseptic or infected arthritis. J. vet. Med. Ser. A, Zbl. Vet. A, 33, 1986: 504-509

KNIGH T, A. D. - LEVICK, J. R.: The density and distribution of capillaries around a synovial cavity. Quart. J. exp. Physiol., 68, 1983: 629-644

KONDOH, Y.: Scanning electron microscope observation of the fine vascular distribution in the syno rial membrane of the dog knee joint. Arch. histol. jap. 35, 1973: 115-126

KRANE, S. M.-AMENTO, E. P.: Cellular interaction and control of collagenase secretion in the synovium. J. Rheumatol., 10 (Suppl. 11), 1983: 7-13

KREY, R.-COHEN, A. A.: The human fetal synovium. Histology, fine structure and changes in organ culture. Arthr. Rheum., 14, 1971: 319-337

LANGER, E.-HUHT, F.: Untersuchungen über den submikroskopischen Bau der Synovial Membran. Z. Zellforsch., 51, 1960: 545-549

LAZARIDES, E.: Intermediate filaments as mechanical integrators of cellular space. Nature (London), 283, 1980: 249-256

LEVER, J. D.-FORD, E. H. R.: Histological, histochemical and electron microscopic observation on synovial membrane. Anat. Rec., 132, 1958: 525-539

LIN CK, G.-PORTE, A.: B-cells of the synovial membrane. I. A comparative ultrastructural study in some mammals. Cell Tissue Res., 187, 1978: 251-261

LUKOSCHEK, M. - SCHAFFLER, M. B.-BURR, D. B.-BOYD, R. D.-RADIN, E. L.: Synovial membrane and cartilage changes in experimental osteoarthrosis. J. orthop. Res., 6, 1988: $475-492$

MAPP, P. I.-REVELL, P. A.: Ultrastructural characterisation of marcophages (type A cells) in the synovial lining. Rheumatol. Int., 8, 1988: 171-176

MARKOWITZ, H.: Synorial fluid proteins. In: Proteins in Body Fluids, Amino Acids and Tumor Markers. New York, A. R. Liss, Inc., E. S. Ritzmınn, L. M. Kllingsworth, 1983

MEACHIM, G. - STOCKWELL, R. A.: The matrix. In: Adult Articular Cartilage. 2nd Edition. London: Pittman Medical, M. A. R. Freeman 1979

OKADA, Y. - NAKANISHI, I. - KAJIKAWA, K.: Secretory granules of B-cells in the synovial membrane. An ultrastructural and cytochemical study. Cell Tissue Res., 216, 1981: 131-141

ROBERTS, E. D.-RAMSAY, F. K. - SWITZER, W. P.-LAYTON, J. M.: Electron microscopy of porcine syno vial cell layer. J. comp. Path., 79, 1969: 41-45

SABISTON, C. P.-ADAMS, M. E.: Production of catabolin by synovium from an experimental model of osteoarthritis. J. orthop. Res., 7, 1989: 519-530

SCHULITZ, K. P.: Synovektomie und Galenkknorpel. Z. Orthrop., 112, 1974: 118-131

SOKOLOFF, L. L.: The joints and synovial fluid. Vol. 2. New York, Academic Press. I. Sokolof, 1980

STOFF, E.-EFFENDY, W.: Development and morphology of rat synovial membrane. Acta anat., 121, 1985: 36-41

SWANN, D. A.: Macronolecules of synovial fluid. In: The Joints and Synovial Fluid. Vol. I. New York, Academic Press, I. Sokoloff, 1978

SWANN, D. A.-HENDREN, R. B.-RADIN, E. L.-SOTMAN, S. L.-DUDA, E. A.: The lubricating activity of synovial fluid glycoproteins. Arthr. Rheum., 24, 1981:22-30

SWANN, D. A.-BLOCH, K. J.-SWINDELL, D.-SHORE, E.: The lubricating activity of human synovial fluid. Arthr. Rheum., 27, 1984: 552-557

SWANN, D. A. - SILVER, F. H. - SLAYTER, H. S.: The molecular structure and lubricating activity of lubricin isolated from bovine and human synovial fluids. Biochem. J., 225, 1985: $195-201$

TOFFT, E.-EFFENDY, W.: Development and morphology of rat synovial membrane. Acta anat., 121, 1985: $36-40$

WASSILEV, W.: Changes in the ultrastructure of the synovial membrane during growth and aging. Verh. Anat. Ges., 69, 1975: 427-431 
Plate I.

Horký D.: Submicroscopic stucture of synovial memb:ane... Plates I. to VI., pp. 3-13.

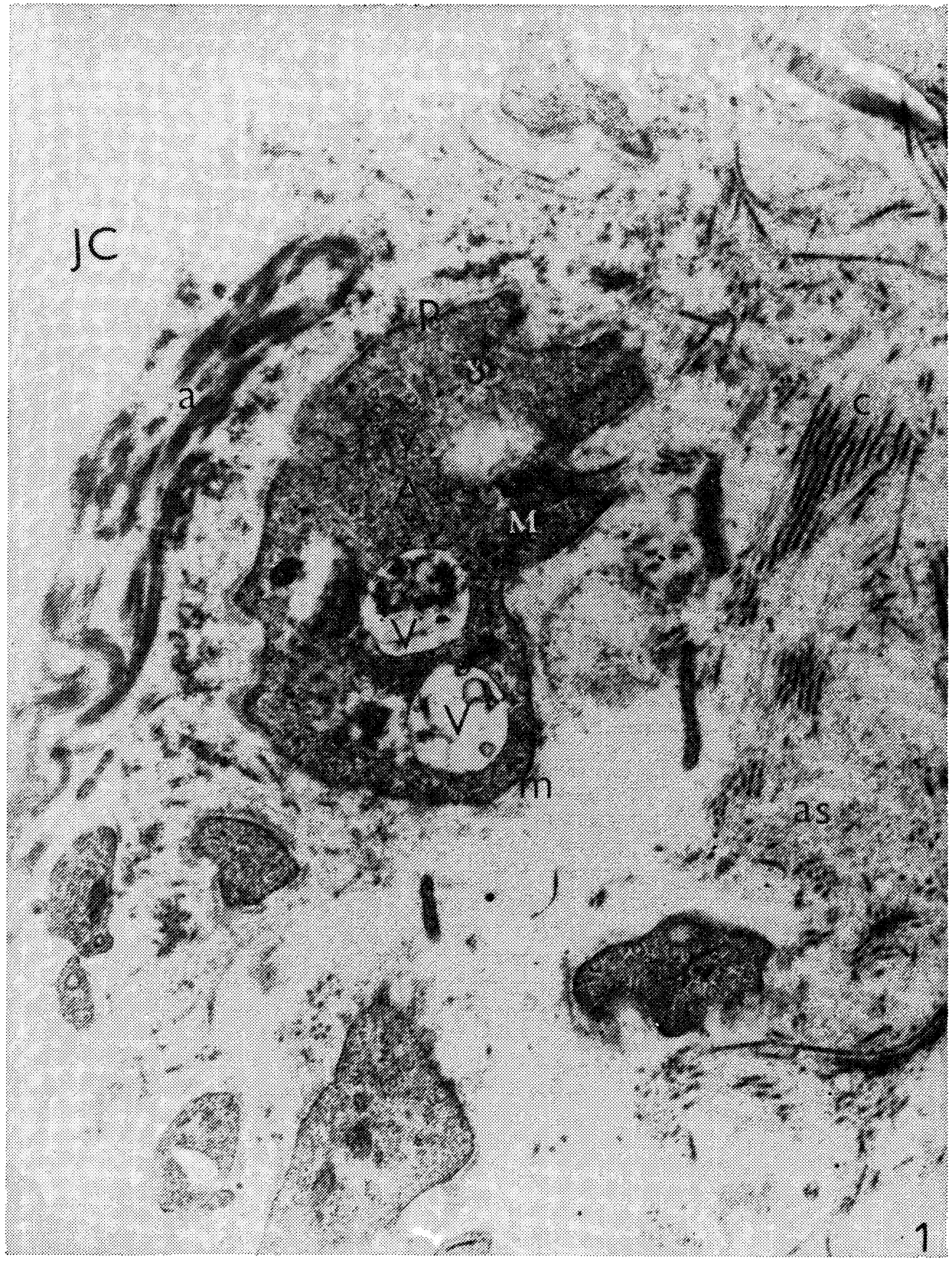

Plate I., Fig. 1: The surface of the synovial membrane. A-cell cytoplasm (A), small (v) and large (V) vacuoles of the agranular endoplasmic reticulum. Mitochondria with dense matrix $(M)$, pinocytotic vesicles (p), basement membrane (m). Bundles of aperiodic filaments (a), collagen fibrils (c), ground amorphous substance (as). Joint cavity (JC). Magnification: $\times 15.000$. 
Plate If.

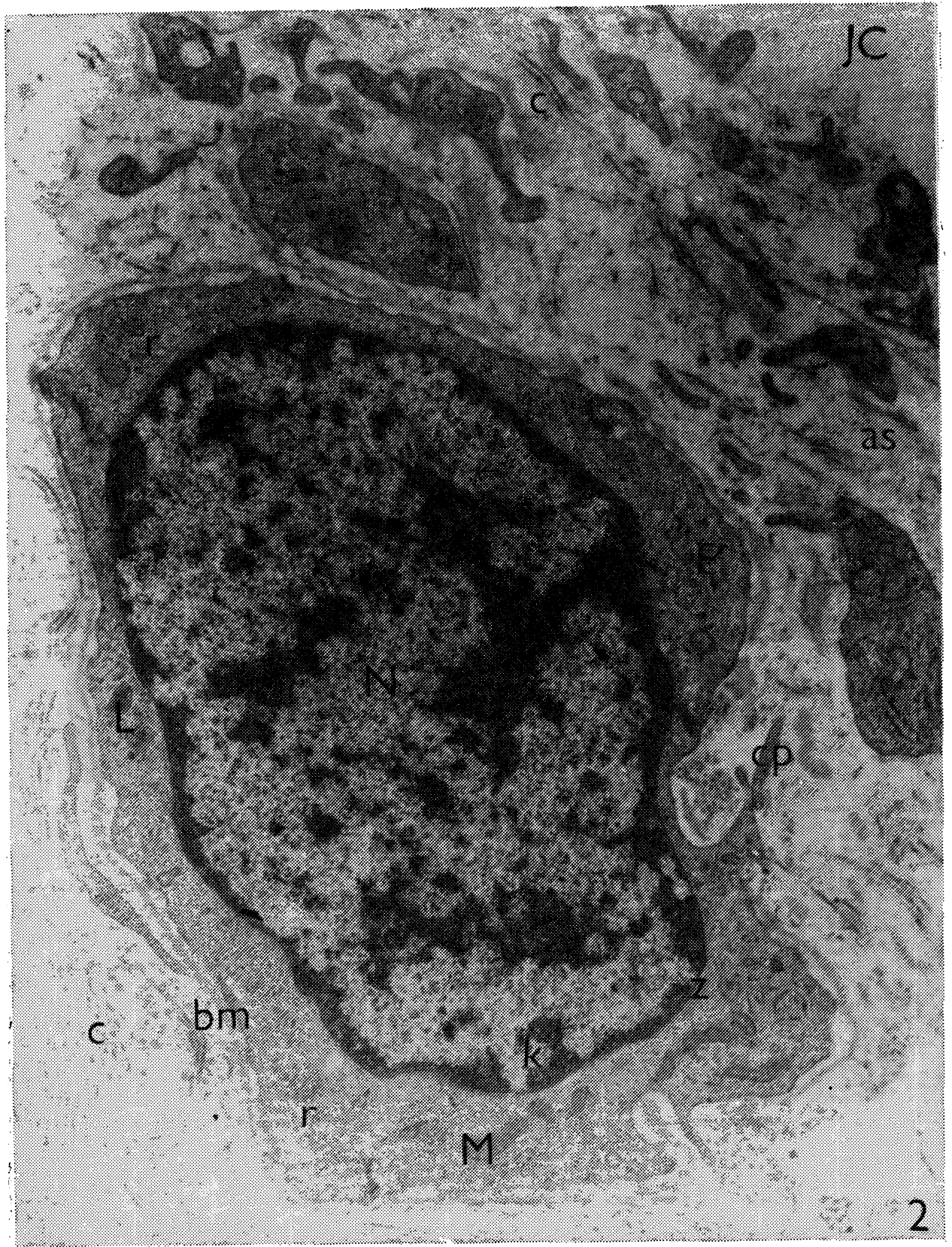

Plate II., Fig. 2: A synovialocyte of A type. Nucleus (N), karyosomes (k), zonula nucleum limitans (z), mitochondria (M), granular endoplasmic reticulum (E), lysosomes (L), ribosomes (r), cytoplasmic projections (cp), basement membrane (bm), collagen fibrils (c), ground amorphous substance (as). Joint cavity (JC). Magnificaiton: $\times 14.500$. 


\section{Plate III.}

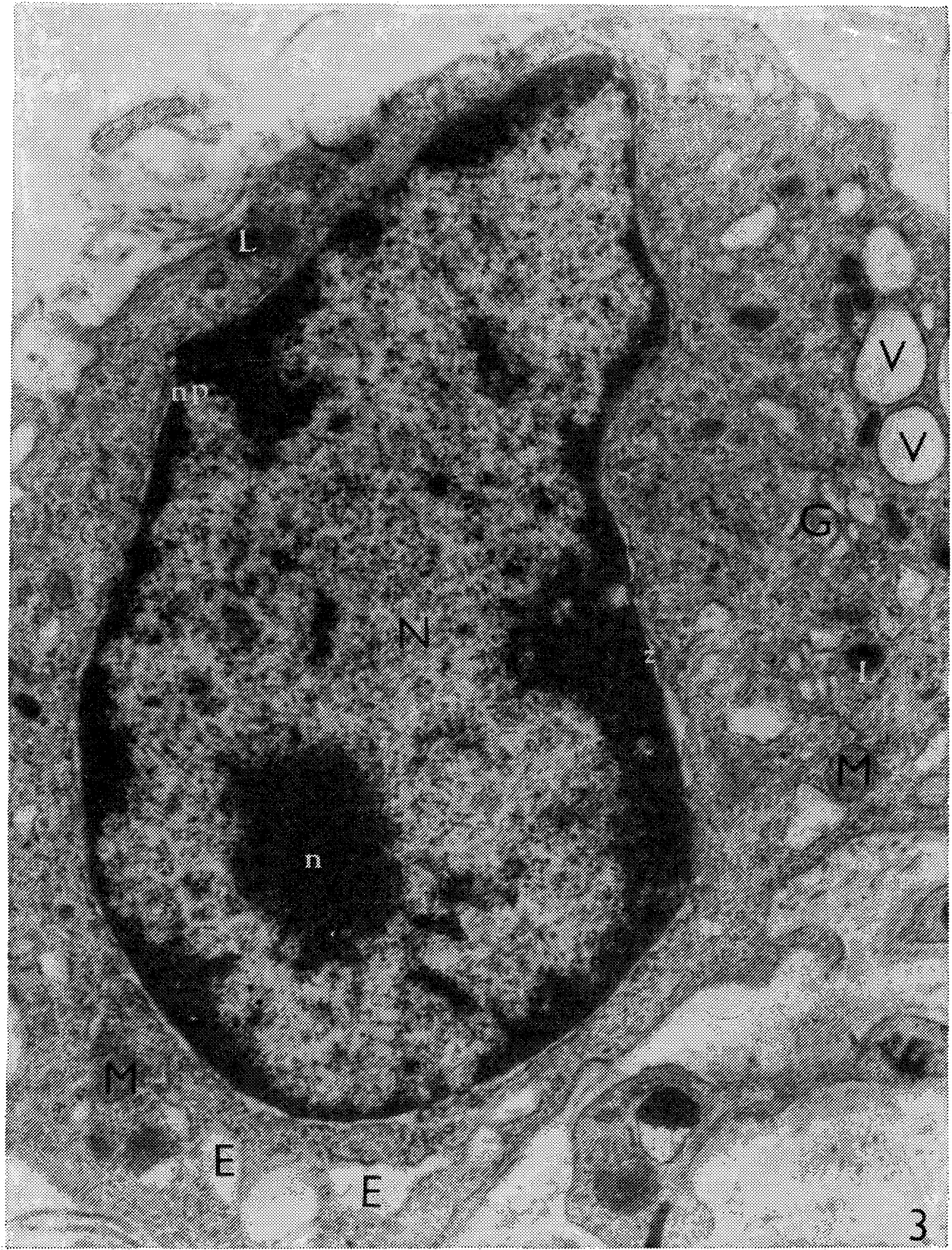

Plate III., Fig. 3: A synovialocyte of transient type. Nucleus (N), nucleolus (n), zonula nucleum limitans (z), nuclear pores (np). Dilation of the granular endoplasmic reticulum (E), large vacuoles of the agranular endoplasmic reticulum (V), lysosomes (L), mitochondria (M), Golgi complex (G). Magnification: $\times 18.000$. 
Plate IV.

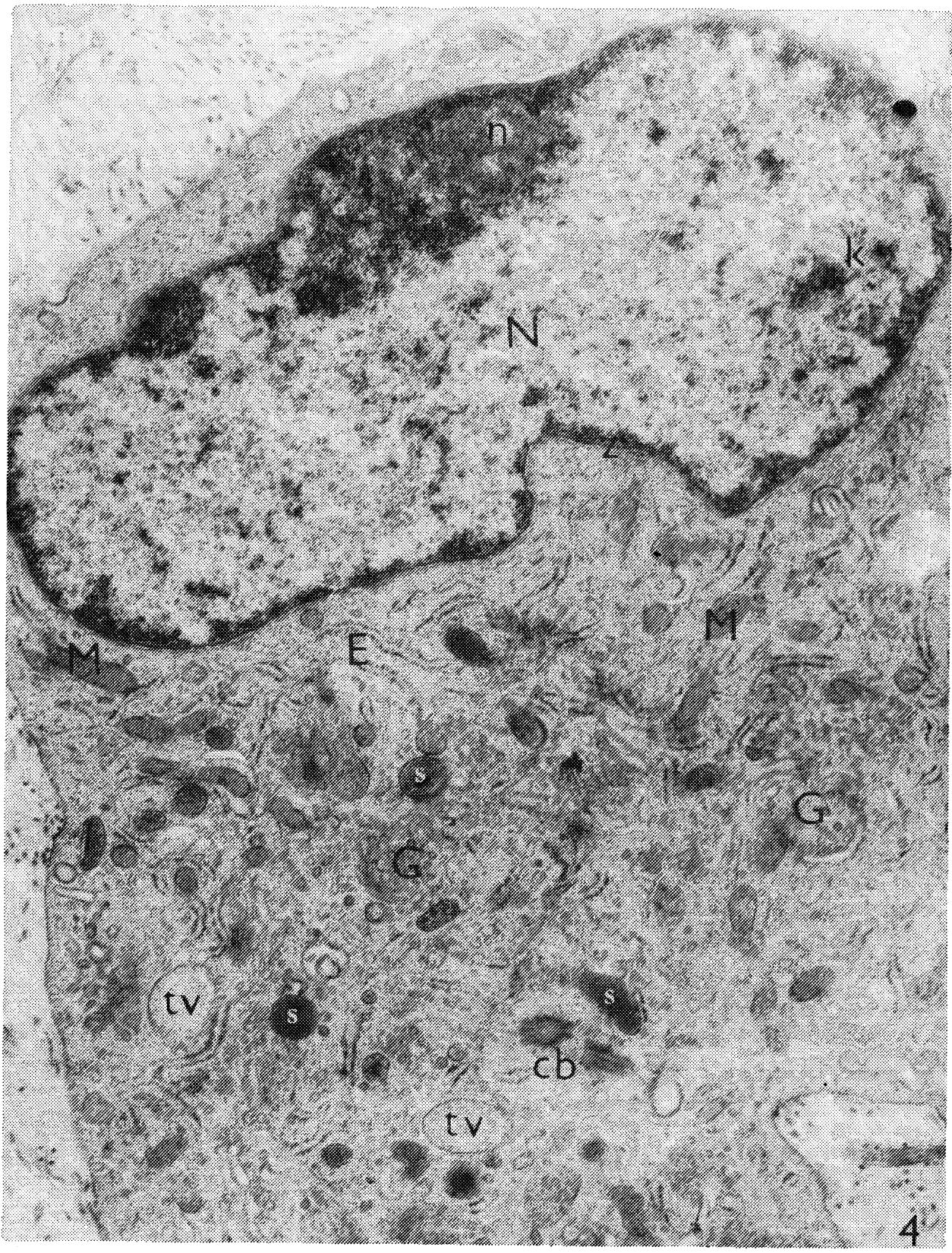

Plate IV., Fig. 4: A synovialocyte of B type. Nucleus (N), nucleolus of reticular type (n), zonula nucleum limitans ( $\mathrm{z}$ ), minute karyosomes (k). Granular endoplasmic reticulum (E) with medium density fibrillar substance. Numerous Golgi fields (G), transport vacoules (tv), centriole (cb), mitochondria $(M)$, secretory granules $(\mathrm{s})$. Magnification: $\times 16.500$. 


\section{Plate V.}

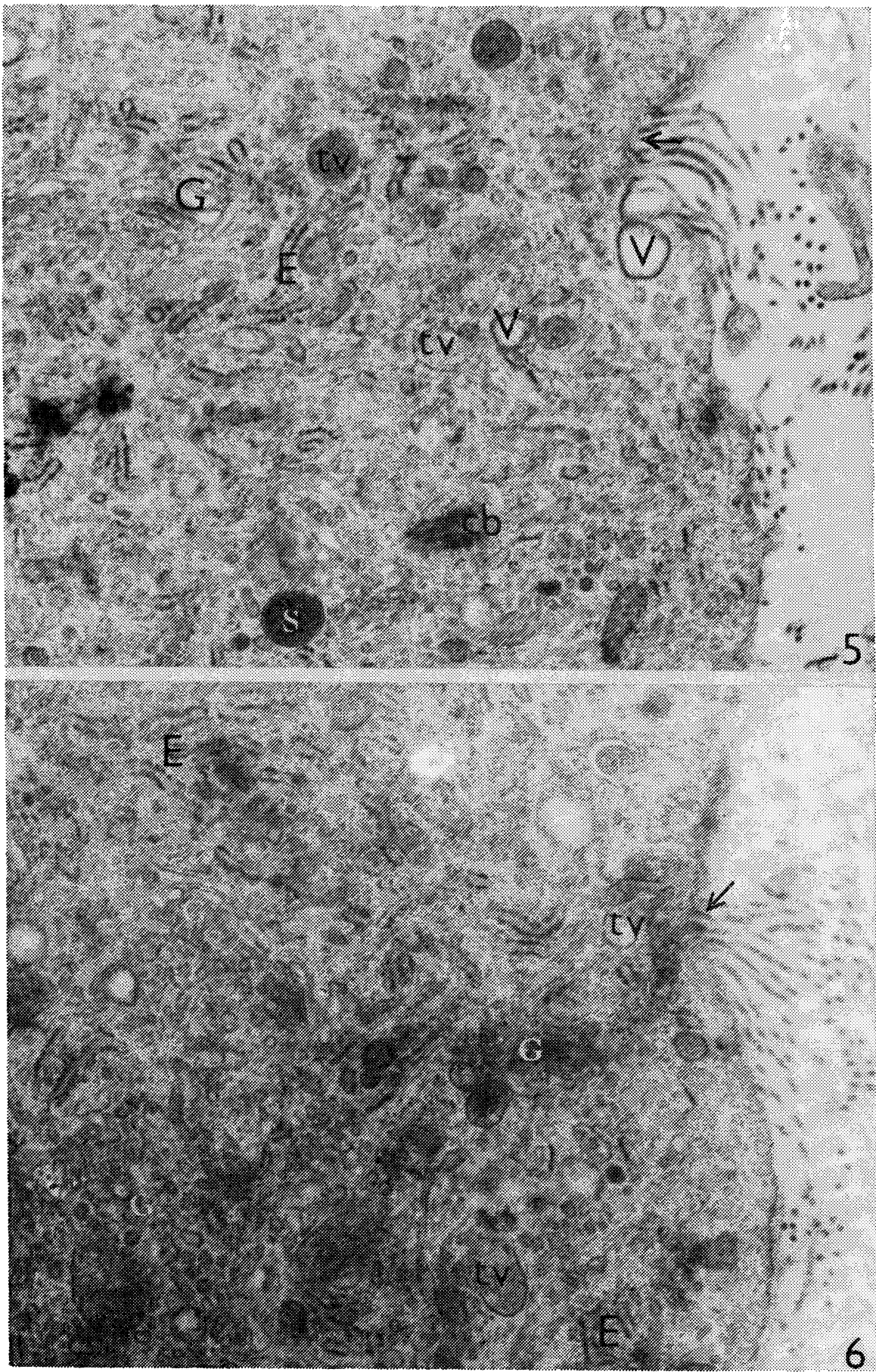

Plate V., Fig. 5: A part of B-cell cytoplasm. Granular endoplasmic reticulum (E), Golgi complex (G), centriole (cb), large vacuoles of the agranular endoplasmic reticulum (V), transport vacuoles $($ tv), secretory granules (s). Passing of collagen fibres through the cell membrane $(\rightarrow)$. Magnification: $\times 20.000$.

Fig. 6: A part of B-cell cytoplasm. A large field of the Golgi complex (G). Transport vacuoles (tv) giving rise to aperiodic collagen fibrils which penetrate through the cell membrane $(\rightarrow)$. Magnification: $\times 21.000$. 
Plate VI.

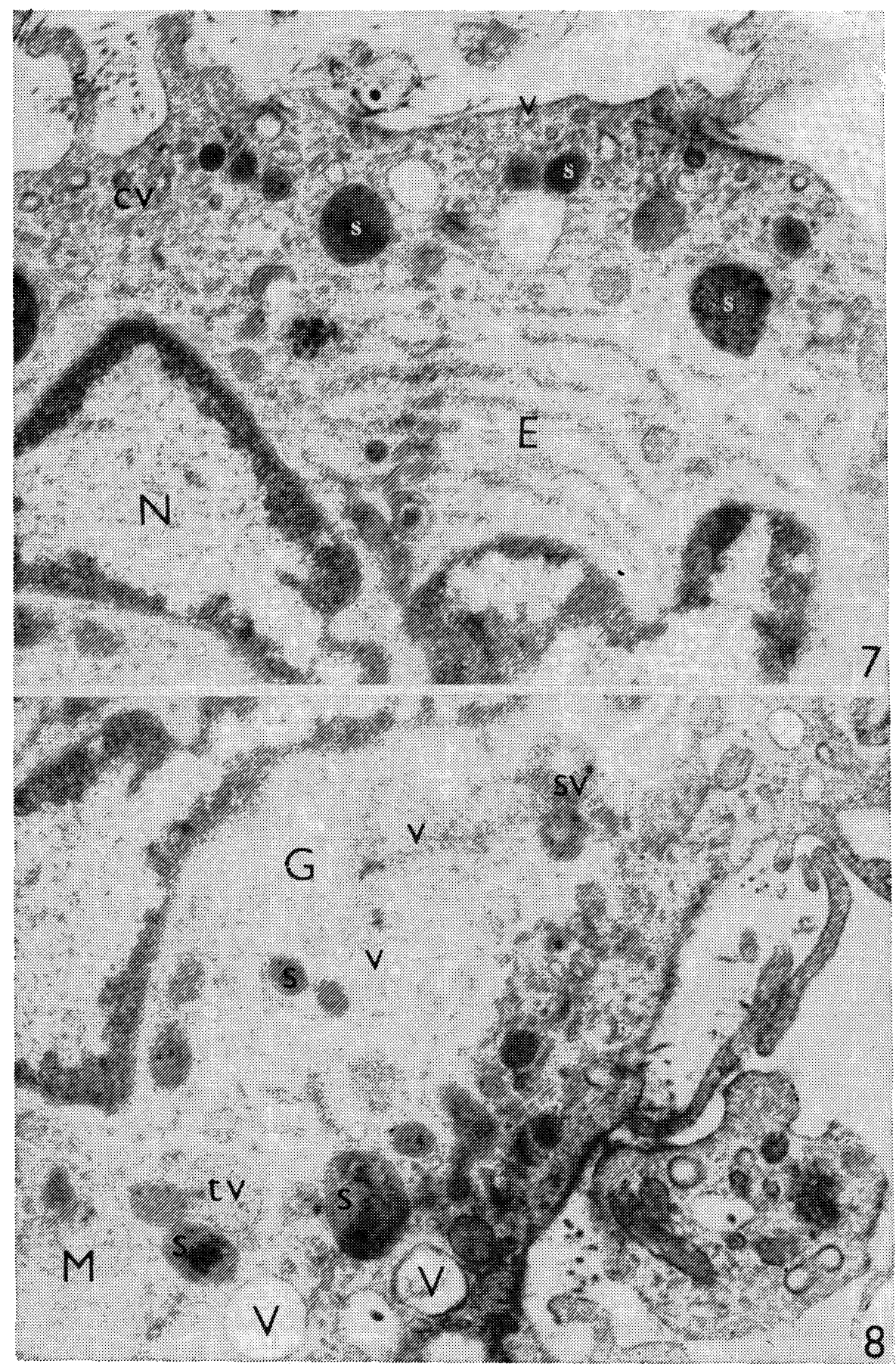

Plate VI., Fig. 7: Nucleus $(N)$ and a superficial part of B-cell cytoplasm. Near the nucleus there are parallelly arranged cisternae of the granular endoplasmic reticulum (E) resembling "annulatea lamellae". Secretory granules (s), numerous pinocytotic vesicles (v), coated vesicles (ov). Magnification: $\times 18.000$.

Fig. 8: A wide Golgi field (G) with numerous small vesicles (v), transport vacuoles (tv) and secretory granules $(i)$. Near the cell membrane there are large vacuoles of the agranular endoplasmic reticulum $(\mathrm{V})$. and scarce mitochondria $(\mathrm{M})$. Several secretory granules with smooth vacuoles (sv). Magnification: $\times 18.000$. 